\title{
Bernard Mandeville and the doctrine of laissez-faire
}

\author{
RENEE PRENDERGAST \\ Queen's University Belfast
}

\begin{abstract}
The view of Mandeville as a pioneer of laissez-faire is difficult to reconcile with his repeated insistence that private vices were turned into public benefits by the 'dexterous management of the skilful politician'. Even if references to the skilful politician are regarded as shorthand for a legal and institutional framework, there remains the question of whether such a framework is a spontaneous order or the product of purposeful experiment as Mandeville thought? Mandeville warned about the harmful effects of meddling but his complaint was about the actions of fashionable do-gooders rather than government. He understood that the voluntariness of a transaction could be regarded as a defence against complaints of unfairness but he was quick to point out the limitations of voluntariness especially in the market for labour. Mandeville's objective was to teach people what they are not what they should be. He pointed to the strengths of the emerging market system but was not afraid to expose its faults.
\end{abstract}

Keywords: Mandeville, laissez-faire, interventionist, education, labour, voluntary action

\section{INTRODUCTION}

In the introduction to his edition of Mandeville's Fable of the bees, F.B. Kaye considered Mandeville's influence in three fields: literature, ethics and economics. Kaye concluded that it was on the course of economic theory that Mandeville's influence was greatest and identified three areas in which this influence was especially important. These were the division of labour, the defence of luxury and most important of all, the doctrine of laissez faire. Kaye saw Mandeville's doctrine of laissez faire as having two interlocking components. One was the beneficial social consequences of political non-interference. The other was that these beneficial social consequences were the result of the unhindered

AUTHOR's NoTE: I am grateful to the referees of this journal and to participants in the Mandeville conference held at the Erasmus University Rotterdam in June 2014 for their comments on earlier drafts of this paper. 
interaction of self-seeking individuals (Kaye, in Mandeville 1924, I: cxxxviii). In support of the first component, Kaye cited the following passage from volume II of the Fable:

In the Compound of all Nations, the different Degrees of Men ought to bear a certain Proportion to each other, as to Numbers, in order to render the whole a well-proportion'd Mixture. And as this due Proportion is the Result and natural Consequence of the difference there is in the Qualifications of Men, and the Vicissitudes that happen among them, so it is never better attained to, or preserv'd, than when nobody meddles with it. Hence we may learn, how the short-sighted Wisdom, of perhaps well-meaning People, may rob us of a Felicity, that would flow spontaneously from the Nature of every large Society, if none were to divert or interrupt the Stream (Mandeville 1924, II: 353).

However, while acknowledging the importance of such passages, Kaye argued that what made the Fable the chief source of the laissezfaire doctrine was not the issue of non-interference but the prominence that Mandeville gave to the doctrine of individualism, ${ }^{1}$ according to which man is seen as a mechanism of interacting selfish passions whose apparent discords harmonise to the public good. Kaye intimated that it was this linking of selfish private interests to the public welfare that provided the philosophical ground for laissez-faire and that, without it, the laissez-faire doctrine could hardly have developed.

Although studies of the ideological basis of classical economics emphasise the importance of the idea that individual self-seeking may entail unintended social benefits, the doctrine of laissez-faire also drew sustenance from other sources (Keynes 1926). The most important of these was the doctrine of natural right, which was developed in the course of the seventeenth century by authors such as Hugo Grotius, Thomas Hobbes, Samuel Pufendorf and John Locke. Building on theories of property and exchange that were present in Roman law, these authors emphasised the right of the individual to the enjoyment of his life, liberty, and property, and regarded transactions entered into voluntarily as inherently just. As Hobbes put it, "forasmuch as both the buyer and

\footnotetext{
${ }^{1}$ Kaye does not provide any formal definition of individualism nor does he adopt Schumpeter's (1908) distinction between political and methodological individualism. However, it is evident from his comparison of Mandeville's thought with his free trade predecessors that Kaye regarded the key difference as follows: "Mandeville held that the selfish good of the individual is normally the good of the state' whereas his predecessors considered the welfare of the state as a whole and that of the individual need not necessarily coincide" (Kaye, in Mandeville 1924, I: cii-ciii).
} 
the seller are made judges of the value, and are thereby both satisfied: there can be no injury on either side" (Hobbes 1999, I: xvi.5). The key change related to the issue of voluntariness. Whereas in earlier thought an exchange was considered to be involuntary and unjust if there was personal compulsion and need, Hobbes was clear that such things as fear could not invalidate a lawful contract (Hobbes 2001, I: xiv.27).

The two justifications for laissez-faire have quite different structures. The first is consequentialist in character; it stresses the beneficial social results. The second is concerned with the rights people have to do things rather than the consequences of their actions. Odd Langholm $(1982,282)$ has suggested that the great strength and longevity of the laissez-faire doctrine derives precisely from the combination of the two justifications. Self-regard is justified by its social benefits, while its less pleasant consequences are tolerated because individuals have a priori rights to do certain things.

No one doubts that Mandeville expressed the view that pursuit of individual self-interest could be beneficial for society and indeed he is widely regarded as the originator of consequentialist arguments for the laissez-faire doctrine. ${ }^{2}$ The issue for commentators has been the conditions under which reconciliation of private and public interests takes place. In defending himself against the suggestion that he was actively promoting vice, Mandeville clarified that the phrase 'private vices, public benefits'-which formed the subtitle of his Fable of the bees-should be interpreted to mean "that private vices by the dexterous management of a skilful politician, may be turned into public benefits" (Mandeville 1924, I: 411-412). This opens up questions concerning the role of the skilful politician and the nature of his dexterous management. The debate surrounding this has generated a substantial literature with important contributions from Viner, Rosenberg, Hayek, and others. This literature is reviewed and evaluated in section II below.

What has not been attended to in the literature to date is the extent to which Mandeville held that the outcome of voluntary transactions is necessarily just or beneficial. ${ }^{3}$ This neglect may be explained by the fact that Mandeville did not subscribe to the idea of a social contract and so

\footnotetext{
${ }^{2}$ The precise nature of these benefits is seldom investigated. Mandeville usually had in mind general prosperity and economic progress, though at times he referred to specific benefits. For a critique of the latter, see Rashid (1985).

${ }_{3}$ No suggestion is being made here that the properties of being just and being beneficial are identical.
} 
would not be expected to use arguments grounded in an appeal to natural rights. Nonetheless, as shown in section III below, Mandeville not only made frequent use of the argument that when a choice is freely made, we can be sure that the person making it regards it as the best option available to him, but he also showed awareness of its ideological force as a justification for otherwise unpleasant states of affairs. But this is not all. While Mandeville generally regarded mutually beneficial exchange of commodities as unproblematic, that was not the case with transactions involving labour. In the labour market, 'voluntary' exchange had to be underpinned by the compulsion of need and Mandeville discussed in some detail what was required for the maintenance of this situation. Almost a century and a half later, Mandeville's observations on the labour market won the approval of Marx, who saw them as providing important insights into the nature of an emerging capitalist system and not simply as a reflection of mercantilist prejudices as has more often been alleged.

\section{INTERVENTIONIST OR NON-INTERVENTIONIST}

The earliest challenge to Kaye's view (that Mandeville's Fable was the chief source of the laissez-faire doctrine) came from Jacob Viner ${ }^{4}$ in the course of his introduction to a reprint of A letter to Dion, which Mandeville wrote in reply to criticisms in George Berkeley's Alciphron. Viner acknowledged Mandeville's rejection of forms of intervention, such as sumptuary laws, as well as his stress on the importance of selfinterest and of individual ambition as the driving forces of economic activity. He also acknowledged that Mandeville held that individual determination would result in a better allocation of labour among different occupations than would regulation. But whilst accepting that these were an essential part of the laissez-faire doctrine, Viner maintained that they were also consistent with mercantilism. According to Viner, in England at least, both mercantilism and the widely-prevalent theological utilitarianism were just as individualistic as later laissezfaire economics. Consequently, Adam Smith was regarded as an exponent of laissez-faire not just because he linked the pursuit of private interest to the public good, but because he maintained as a general principle that the activities of government should be limited to

\footnotetext{
${ }^{4}$ In his earlier Studies of the theory of international trade, Viner $(1937,99)$ accepted Kaye's evaluation referring to Mandeville's elaborate reasoning in support of individualism and laissez-faire as preparing the way for Adam Smith.
} 
the enforcement of justice, to defence, and to public works. Mandeville, by contrast, "put great and repeated stress on the importance of the rôle of government in producing a strong and prosperous society, through detailed and systematic regulation of economic activity" (Viner 1953, 13). It was a common mistake to interpret the sub-title of the Fable 'Private Vices, Publick Benefits' as a laissez-faire motto, but Mandeville, himself, had repeatedly emphasised the importance of "the dexterous Management of a skilful Politician" (Viner 1953, 13-14).

In a paper published in 1963, Nathan Rosenberg sought to address the problems posed by these conflicting interpretations of Mandeville. Rosenberg acknowledged that Mandeville was a mercantilist in the sense that attributed great importance to the regulation of a country's balance of trade with the rest of the world. However, he qualified this by noting that Mandeville's emphasis on the balance of payments appears to have been motivated by his desire to demonstrate that, contrary to the conventional wisdom, a taste for foreign luxury could not undo a nation (Rosenberg 1963). Turning to the domestic affairs, Rosenberg argued that Mandeville presented a well-articulated position on the role of government in social and economic affairs, which was considerably more interesting than that comprehended in the intellectual tradition of laissez-faire or, for that matter, mercantilism. Mandeville, he argued, was indeed an interventionist, but the forms of intervention that he approved were such as would result in the creation of a society which would run itself. Thus, when Mandeville referred to private vices being turned into social benefits by the dexterous management of the skilful politician, he was not advocating political intervention in the day-to-day management of the economy. Rather, he was advancing the view that the welfare of society is best promoted by the introduction and diffusion of laws that utilize man's basic passions and channel them into socially useful activities. In other words, Mandeville's dexterous management by the clever politician was not to be interpreted literally; it referred to the creation of a legal and institutional framework where arbitrary exertions of government would be minimised. Such a framework was not to be regarded as the product of human ingenuity or of a single mind but evolved gradually over time through a process of trial and error (Rosenberg 1963).

The broad thrust of Rosenberg's interpretation of Mandeville with its emphasis on the evolutionary development of social institutions is 
widely accepted. ${ }^{5}$ However, as we shall see, its effect was not to end the arguments about Mandeville and laissez-faire but to move them to a different level. In his 1966 lecture on Mandeville delivered to the British Academy, Hayek expressed the view that Rosenberg was "wholly right" in his interpretation of Mandeville, and intimated that Viner had been misled by Mandeville's references to "dexterous management by the skilful politician" (Hayek 1991). While the focus of the lecture was Mandeville's evolutionary views rather than his attitude to laissez-faire per se, it nonetheless had important bearing on the issue since Hayek characterised Mandeville's evolutionary views on the development of institutions as an early statement of the doctrine of spontaneous order. Hayek's view is well summarised in a note on Mandeville written in 1959:

Not only in the areas of morality and convention, but also for language and money, he [Mandeville] shows clearly how the preservation of more advantageous and the elimination of less profitable practices and usages leads to cumulative growth of extremely complicated structures which serve human goals and form the basis of culture without ever having been consciously designed (Hayek 1991, 99).

Hayek and Rosenberg are in agreement that Mandeville's "dexterous management" is to be achieved not by continuous government intervention in the market process but by means of laws and institutions which evolved over time that channel human energies in ways that are socially beneficial (Rosenberg 1963, 188). They also agree that these laws and institutions are the products of an evolutionary process taking place over very long periods of time and, in this sense, can be regarded as the product of human action rather than human design. However, whereas Rosenberg argued that, for Mandeville, laws and institutions were in a meaningful sense the products of wise government, Hayek saw in Mandeville an early statement of the doctrine of spontaneous order-that is, an order which has evolved over time without the intervention of government. Although views differ on what exactly Hayek believed about the efficiency of evolved institutions, there

\footnotetext{
5 For example, Chalk (1966) regards Rosenberg's analysis as "convincing" and "thorough". On the other hand, while describing Rosenberg's interpretation of Mandeville's views on the evolutionary development of social institutions as "faultless", Landreth (1975, n76) argues that Rosenberg missed the main point, viz., Mandeville's emphatic assertion of the necessity of government to bring harmony between individual self-interest and public welfare.
} 
can be no doubt that he was a reluctant reformer, an advocate of gradualism, and an enemy of what he called constructive intervention. Apart from any propensity to believe in the proven utility of evolved organisations, Hayek also grounded his gradualism in the belief that people lacked the knowledge to enable them to intervene effectively in complex evolved institutions.

Mandeville was also deeply conscious of the limitations of our knowledge ${ }^{6}{ }^{6}$ but he appears to have had no objection to a considerable amount of reforming effort. He defined society as a body politic in which man had become a disciplined creature that can find his own ends in labouring for others "and where under one head or other form of government each member is rendered subservient to the whole" (Mandeville 1924, I: 347). The role of government was to preserve peace and tranquillity among multitudes of different views, and make them all labour for one interest. It was the "business of the public to supply the defects of the society, and take that in hand which is most neglected by private persons" (ibid., 321). The art of governing was "a great task [...] and nothing in human affairs required greater knowledge" (II: 318). The regulations required to defeat and prevent all the machinations and contrivances that arise from avarice and envy were infinite. In a city such as London, "the laws, prohibitions, ordinances, and restrictions that have been found absolutely necessary, to hinder both private men and bodies corporate, in so many different stations, first from interfering with the public peace and welfare; secondly, from openly wrongdoing and secretly overreaching, or any other way injuring one another [... were] prodigious beyond imagination" (II: 321). Very few institutions were the work of one man or even one generation. The wisdom they involved was not the product of a fine understanding or intense thinking but of sound and deliberate judgement, acquired from long experience in business and a multiplicity of observations (II: 322). Hence, if we examine the governance of a flourishing city which has lasted a long time, we will find:

\footnotetext{
${ }^{6}$ There are discussions of the nature and limitations of human knowledge in the 3rd and 4th dialogues of Part II of the Fable and in A treatise of the hypochondriack and hysterick diseases, 1730. Mandeville's analysis of knowledge is discussed in Prendergast (2014).
} 
That the changes, repeals, additions and amendments, that have been made in and to the laws and ordinances by which it is ruled, are in number prodigious: But when they are once brought to as much perfection, as art and human wisdom, can carry them, the whole machine may be made to play of itself, with as little skill, as is required to wind up a clock (II: 323).

All of this would seem to indicate that in Mandeville's view the evolution of laws and institutions involved active intervention by government and law makers. Mandeville was aware that, like everyone else, legislators possessed only limited rationality. As he it put in his Modest defence of public stews (1724), no society ever framed a complete body of laws at once. Unforeseen events were likely to happen and these would require subsequent modification of any initial proposals or actions (Primer 2006, 62).

As noted above, Hayek was of the view that Viner had been misled by Mandeville's repeated reference to dexterous management by the skilful politician and had misinterpreted this to mean that Mandeville favoured "what we now call government intervention, that is, a specific direction of men's economic activities by government" (Hayek 1991, 85). Viner, however, appears to have been unmoved and expressed this in a letter to Hayek of January 23rd, 1967, in which he wrote: "I see nothing to withdraw, to amend, or to justify in what I have written about Mandeville" (Hayek 1991, 85; Skarbek 2013). Viner also pointed out that although Mandeville was a staunch supporter of the Whig government of his day, there was no record of his having criticised any interventionist laws of the period other than those involving discrimination against dissenters and the exclusion of protestant immigrants (Hayek 1991b, 85).

Viner's concerns about what he perceived as biases and inconsistencies in Hayek's position had already been articulated in his review of Hayek's The constitution of liberty in 1961 and also in his own article on the intellectual history of laissez-faire published in 1960. Two related points from these publications will concern us here. The first concerns Hayek's contention that the development of desirable institutions should be left to the play of spontaneous forces, which he believed can be relied upon to produce good results because no institution can continue to survive unless it performs some useful function. Viner complained of Hayek's failure to examine the historical evidence relating to the rise, persistence, and fall of historical 
institutions. Tellingly, he also complained about Hayek's failure "to apply the method of speculative history to government itself" and to treat it "as itself an institution which is in large degree a spontaneous growth, inherently decentralised, experimental, innovating, subject not only to tendencies for costly meddling but also to propensities for inertia and costly inaction" (Viner 1961, 235).

The second point relates to the bias in favour of the status quo. This is a natural consequence of the assumption that existing institutions must have wisdom and merit in them because they are the product of an evolutionary process (Viner 1960, 63). Viner argued that if this assumption were valid, it would at most imply that interventions should be cautious and piecemeal. In any case, it provided no warrant against "selective tampering with the free market process by a government wellintentioned and reasonably intelligent" (1960, 64). Such tampering could be warranted even in "cases of free contract between two individuals". In this context, Viner went on to challenge Bentham's view that no government or official can know what somebody wants or the means of fulfilling those wants better than the person himself $(1960,65)$.

Implicit in Viner's critique are doubts about the 'optimality' of both the actual market process as well as the evolutionary processes outlined by Hayek. Viner is by no means alone in this. Hayek has been widely criticised even by allied authors, such as Buchanan, for implying that the persistence of a form of life indicates that it is in some sense ideal or legitimate (Buchanan 1975; Gray 1989; Voight 1992, Brennan 2013).7 The work of authors such as Paul David (1985), Brian Arthur (1989), and Paul Krugman (1991) has demonstrated the importance of positive feedbacks and the possibility that societies could be locked-in to inferior conventions, standards and technologies. Likewise, game theoretic approaches have failed to provide any comfort for those wishing to argue in defence of the status quo. In a perceptive article focussed on Mandeville, Marina Bianchi (1993) pointed out that Hayek neither explains what he means by socially beneficial institutions nor how such institutions are reached, maintained, or changed. Bianchi showed that repeated games of the co-ordination type were helpful in representing

\footnotetext{
${ }^{7}$ In addition to the works cited above, there is a large literature on the issue of group selection, namely on whether it can provide an adequate mechanism for cultural evolution in Hayek (Caldwell 2000; Whitman 1998; Sober and Wilson 1988; Steele 1987; Fiori 2006). Although Mandeville, in his conjectural history of the origin of moral virtue, has the lawgivers and other wise men divide the species into two classes to create an emulation among them, what he describes is hardly what Hayek means by group selection.
} 
the spontaneous emergence of norms. However, such conventions were not necessarily the most efficient and, where they were not, the shift to a more efficient solution could not happen spontaneously but required active intervention (Bianchi 1993; Rosenberg 1963; Rutherford 2001). Norms can also emerge in prisoners' dilemma type games which continue in time but the means by which they do so are not well understood. As Bianchi points out, the solutions usually proposed involve the restructuring of the problem as if interests necessarily converge on the commonly beneficial outcome. Bianchi argues that this does not do justice to Mandeville whose depiction of society involves a constant search for innovations yielding differential advantage and whose formulation of market society is one in which beneficial 'consequences' arise not despite individual conflicts of interest but because of them.

This aspect of Mandeville's thought was noticed, and evidently admired, by Marx who parodied Mandeville's arguments in a passage in the Economic manuscript of 1861-63. The passage begins: "A philosopher produces ideas, a poet poems, a clergyman sermons, a professor compendia and so on. A criminal produces crimes". It continues:

If we take a closer look at the connection between this latter branch of production and society as a whole, we shall rid ourselves of many prejudices. The criminal produces not only crimes but also criminal law, and with this also the professor who gives lectures on criminal law [...]. The criminal breaks the monotony and everyday security of bourgeois life. In this way, he keeps it from stagnation, and gives rise to that uneasy tension and agility without which even the spur of competition would get blunted. Thus he gives a stimulus to the productive forces [...]. Would locks ever have reached their present degree of excellence had there been no thieves? [...] Does not practical chemistry owe as much to the adulteration of commodities and the efforts to show it up as the honest zeal for production? (Marx 1988, 306-309).

Marx concluded with the statement that Mandeville had already shown that every possible kind of occupation is productive, and he quoted Mandeville's view that what we call evil in this world, moral as well as natural, is the grand principle that makes us sociable creatures. Marx added, "Only Mandeville was of course infinitely bolder and more honest than the philistine apologists of bourgeois society" (Marx 1988, 
310). ${ }^{8}$ Like Mandeville, Marx evidently enjoyed disturbing bourgeois sensibilities, but his parody pinpoints the fact that, for Mandeville, it is the clash of interests rather than their identity that drove economic progress.

Rashid $(1985,322)$ regards Mandeville's assertions about the benefits of fraud as nonsensical, and indeed Mandeville himself cautioned against drawing conclusions in infinitum from some of his paradoxical assertions. However, the key point is that things that are undesirable in the short-term may lead to a variety of improvements if viewed in a longer time frame. ${ }^{9}$ In the essay, A search into the nature of society and in volume II of the Fable, Mandeville argued that neither the friendly qualities of man nor the bounty of nature gave rise to development. Rather "the necessities, the vices and imperfections of man, together with the various inclemencies of the air and other elements, contain in them the seeds of all arts, industry and labour" (Mandeville 1924, I: 366).

Mandeville insisted that genius, wit, and natural parts could be as much improved in the practice of the meanest villainy, as in the exercise of industry or the most heroic virtue (I: 275). Nonetheless, he understood that the system could not function if everybody behaved badly. Those who strove only to gratify their appetites would find themselves "continually crossed by others of the same stamp". Consequently, "they could not but observe that whenever they checked their inclinations or but followed them with more circumspection, they avoided a world of troubles, and often escaped many calamities that generally attended the too eager pursuit after pleasure" (I: 47). While such observations were the philosophical reason for accepting restraints on behaviour, Mandeville was of the view that forms of tractable behaviour were not the result of reflection but achieved gradually over long periods of time through the pursuit of self-preservation or through the skilful management of politicians who flattered men's pride using honours and other imaginary rewards (II: 139; I: 51).

Like Mandeville, Adam Smith emphasised that economic development was the main source of improvements in the standard of

\footnotetext{
${ }^{8}$ Marx did not elaborate further and, in spite of his reference to the development of the forces of production, he did not comment on the evolutionary aspect of Mandeville's thought. All of Marx's quotations from Mandeville are from the first volume of the Fable so it is possible that he was not acquainted with the more developed evolutionary thought of the volume II.

${ }^{9}$ For a recent discussion of the difference between static and dynamic approaches in the context of environmental protection, see Porter and Van der Linde (1995).
} 
living. ${ }^{10}$ In Smith's case, development was linked to the accumulation of capital and the case for non-intervention was that interference would lead to the misallocation of capital and slow the rate of accumulation. Mandeville had no theory of capital accumulation. Progress depended on the sustained accumulation of knowledge which, in turn, required the preservation of existing knowledge through education and training, as well as the addition of new knowledge to that inherited from the past (Prendergast 2010; 2014). Such additions were due to the innovations of active stirring men easily reconciled to the bustle of the world who pursued their aims with eagerness and assiduity (Mandeville 1924, II: 111). But while such eagerness was necessary for innovation, it had to be "lopt and bound" by justice and other social institutions lest it become dysfunctional.

\section{THE MERITS OF FREE CHOICES}

Before examining Mandeville's references to the question of free choice, it will be useful to refer briefly to the ways in which free choice is considered in modern economic literature. One view, in the spirit of Locke, Nozick and Rothbard, is that choices and contracts made voluntarily are good by virtue of the fact that they are expressions of the will or right of the parties concerned. A different approach to the merits of free choice can be found, for example, in Friedman who argues that the outcome of free exchange is necessarily good because where a transaction is informed and bi-laterally voluntary, it will only be engaged in if it brings benefits to both parties. In this view of things, voluntary transactions are valued not just because they are voluntary but because they produce good outcomes for the contracting individuals. ${ }^{11}$

As noted earlier, the view that the outcome of transactions made voluntarily will be beneficial for all the parties involved has its origins in Roman law and is summarized in the maxim that a thing is worth what it can be sold for in the absence of force, fraud and deceit (Langholm 1982; Lupton 2015). Langholm has argued that, in Aristotelian and scholastic thought, the criterion for voluntariness was strict, with no distinction being made between personal coercion and personal

\footnotetext{
${ }^{10}$ Bitterman (1940) and Spengler (1959) argue that the case for laissez-faire in Smith is based on gains through the division of labour and the accumulation of capital, rather than any supposed identity of interests.

${ }^{11}$ See Friedman (1991). While Friedman emphasised the instrumental value of economic freedom, his valuation of economic freedom was not purely instrumental.
} 
compulsion in the form of need (Langholm 1982). The scholastics' effort to modify Roman legal liberalism by applying strict criteria of voluntariness was swept aside during the seventeenth century; this is seen in the works of Grotius and Pufendorf and, most of all, in Hobbes who took the view that there could be no injury where exchanges were made voluntarily. Mandeville's thinking on the matter appears to be very much in the new liberal spirit: market transactions would take place only when both parties expected to benefit from the exchange:

How to get these services performed by others, when we have occasion for them, is the grand and almost constant solicitude in life of every individual person. To expect that others should serve us for nothing is unreasonable; therefore all commerce, that we can have together, must be a continual bartering of one thing for another. The seller, has his own interest as much at heart as the buyer, who purchases that property; and if you want or like a thing, the owner of it, whatever stock or provision he may have of the same, or how greatly soever you may stand in need of it, will never part with it, but for a consideration which he likes better, than he does the thing you want (Mandeville 1924, II: 349).

Elsewhere in the Fable, Mandeville had explained that actions and choices that were freely made are to be regarded as the best available to the individual: "in the choice of things, men must be determin'd by the perception they have of happiness; and no person can commit or set about an action, which at that then present time seems not to be the best to him" (II: 178). In response to the challenge that one might choose against their better judgment, Mandeville continued:

Every motion in a free agent which he does not approve of, is either convulsive or it is not his; I speak of those that are subject to the will. When two things are left to a person's choice, it is a demonstration, that he thinks that most eligible which he chuses, how contradictory, impertinent or pernicious soever his reason for chusing it may be: without this there would be no voluntary suicide and it would be an injustice to punish men for their crimes (II: 1789).

Although he took pains to argue that people would always seek to make the choices that appeared to be the best available in the particular circumstances, Mandeville was aware that problems could arise if quality were difficult to judge or information were lacking. For example: 
If the butcher sends us home stinking meat, or the shoe-maker sells us bad leather, they lose our custom, because everybody can judge the imposition which makes them honest in their own defence; but what obligation lie they under to be so, quorum scelera terra tegit [whose villainies the earth covers] (Mandeville 1730, 348).

The information issue was discussed in the context of a bargaining session between two merchants haggling over a price of a cargo of sugar. In the course of the bargaining, the seller receives news of events which would be expected to lower the future market price of sugar. This makes him more eager to do business now though he endeavours to conceal this fact. A little later, the buyer receives news that would drive the market price in the opposite direction. When the bargain is concluded, it is the buyer who reaps the benefits. Remarking that each party to the contract strove to over-reach the other, Mandeville comments: "yet all of this is called fair dealing; but I am sure neither of them would have desired to be done by, as they did to each other" (Mandeville 1924, I: 63). ${ }^{12}$ This example shows that misinformation may cause the actual benefits from a transaction to differ from those that were expected. It also serves to illustrate that "fair dealing" in the market has little to do with the Christian teaching, which requires that you should do to others as you would have them do to you.

As we shall see, however, Mandeville recognised that it would be possible to attach 'moral' worth to choices freely made. In a wellknown $^{13}$ passage on the division of labour in volume I of the Fable, Mandeville itemizes the multiplicity of trades in different parts of the world that were required to produce a crimson cloth. Towards the end of the passage, Mandeville writes that when we are acquainted with the toil, labour, hardships, and calamities that must be undergone in order to produce such an article, "it is scarce possible to conceive a tyrant so inhuman and devoid of shame, that [...] he should exact such terrible services from his innocent slaves" (I: 357). Things looked different, however:

if we turn the prospect, and look on all those labours as so many voluntary actions, belonging to different callings and occupations

\footnotetext{
${ }^{12}$ Examples such as this have led some commentators, e.g., Moss (1987), to argue that Mandeville had a zero-sum view of the market process. This does not seem to be in line with Mandeville's general position with regard to exchange.

${ }^{13}$ The passage is well known at least in part because Adam Smith's discussion of the division of labour in chapter 1 of Wealth of Nations borrows extensively from it, although Mandeville is not referenced.
} 
that men are brought up to for a lively hood, and in which everyone works for himself, how much soever he may seem to labour for others: [...] If we consider, I say, and look on these things in another view, we shall find that the labour of the poor is so far from being a burthen and an imposition upon them; that to have employment is a blessing, which in their addresses to heaven they pray for (I: 358).

With an eye for paradox, Mandeville had noted that whether the labour of the poor was viewed as a curse or as a blessing would depend on how one looked at it. ${ }^{14}$ However, Mandeville was not content to simply to identify the paradox; he sought to uncover the circumstances by which "in a free nation where slaves were not allow'd of" multitudes of laborious poor would be willing to perform the hard unpleasant work (Mandeville 1924, I: 287-8). Part of his answer was that labourers should be kept poor; just as the poor "ought to be kept from starving, so they should receive nothing worth saving". Furthermore:

Those that get their living by their daily labour [...] have nothing to stir them up to be serviceable but their wants, which it is prudence to relieve, but folly to cure. The only thing that can render the labouring man industrious, is a moderate quantity of money; for as too little will [...] either dispirit him or make him desperate, so too much will make him insolent and lazy (I: 193).

In addition to being kept poor, he maintained that they should be kept ignorant as well:

The knowledge of the working poor should be confined within the verge of their occupations and never extended [...] beyond what relates to their calling. The more a shepherd, a plowman or any other peasant knows of the world, and the things that are foreign to his labour or employment, the less fit he will be to go through the fatigues and hardships of it with chearfulness and content (I: 288).

\footnotetext{
${ }^{14}$ The idea that things were evaluated differently depending on how one looked at them is ubiquitous in Part I of the Fable. Mandeville delighted in uncovering paradoxes and contradictions and in mocking the one sidedness and hypocrisy which he saw all around him. For example, having first established the evil nature of the trade in alcoholic spirits in Remark 'G', Mandeville proceeded to show that a good humoured man might look at things differently and view them as a universal comfort for the poor, as well as a source of great wealth for some eminent distiller. Against the objection that the wealth of one rich man could not compensate for the misery of thousands of poor, Mandeville satirically pointed out that such a man could be active in encouraging the reformation of manners and become the scourge of the very class of men to whom he owed his fortune (Mandeville 1924, I: 86-93).
} 
Those who spent a great part of their youth in learning to read, write and cypher, expect [...] to be employed where these qualifications may be of use to them; the generality of them will look upon downright labour with the utmost contempt, I mean labour performed in the service of others in the lowest station of life, and for the meanest consideration. A man who has some education may follow husbandry by choice, and be diligent at the dirtiest and most laborious work; but then the concern must be his own, and avarice, the care of a family, or some other pressing motive must put him upon it; but he won't make a good hireling and serve a farmer for a pitiful reward (I: 289).

Mandeville recognized that there would be backlash against these sentiments, and that it was barbarous that the children of the poor should be deprived of opportunities if they had as much natural ability as the rich (which is what he believed to be the case). In response he claimed that if someone from the lowest class lifted him or herself out of their condition by way of uncommon industry, nobody should hinder them (I: 193). He also argued that being deprived of opportunity was no worse than not having money when the poor had the same inclinations to spend as others. There was an abundance of hard, dirty labour to be done, and coarse living to be complied with. Nobody would do this work if not obliged to do it, and so there was no "better nursery for these necessities than the children of the poor? None certainly are nearer to it or fitter for it" (I: 311).

It is not that Mandeville thinks that opportunity is unimportant. He knows that it is:

Reading, writing or arithmetic would never be wanting, in the business that requires them, though none were to learn them but such whose parents could be at the charge of it. It is not with letters as it is with gifts of the Holy Ghost, that they may not be purchased with money; and bought wit, if we believe the proverb, is none the worst (I: 298).

Mandeville's point is that if someone is to experience hardship, it should be those who are brought up to it: "the things [...] called hardships, neither seem nor are such to those who have been brought up to them, and know no better" (I: 311).

Hence, while Mandeville understood that it was possible to 'justify' the nasty, brutish conditions endured by the working class on the basis that individuals would prefer to be employed rather than in want of 
work, he was under no illusion that work would be freely chosen in all circumstances (I: 317):

No man would be poor and fatigue himself for a livelihood if he could help it: The absolute necessity all stand in for victuals and drink, and in cold climates for clothes and lodging, makes them submit to anything that can be bore with. If nobody did want no body would work; but the greatest hardships are looked upon as solid pleasures, when they keep a man from starving (I: 287).

Mandeville returned to this in part II of the Fable. There, he argued that there was a big difference between disallowing poor children from rising out of poverty and refusing them education when they could be more usefully employed (II: 352). Mandeville assumed that all the hard and dirty labour in the kingdom required a fixed amount of labour to accomplish it. Consequently, if some of the existing workforce were to rise in the world, their place would have to be taken by others or there would have to be a reduction in the amount of work done. Hence, charity to some might prove cruel to others. It was in this context that Mandeville stated the following:

In the Compound of all Nations, the different Degrees of Men ought to bear a certain Proportion to each other, as to Numbers, in order to render the whole a well-proportion'd Mixture. [...] [I]t is never better attained to, or preserv'd, than when nobody meddles with it (II: 353).

This declaration of the 'laissez-faire principle' was not opposed to government intervention, but was opposed to the "short-sighted wisdom of well-meaning people" in this case, the fashionable meddling of those who promoted charity schools. ${ }^{15}$ The same applies to Mandeville's other statement of the principle which occurs in the essay on charity and charity schools in volume I of the Fable. Having pointed to "[t]he variety of services that are required to supply the luxurious and wanton desires as well as the real necessities of man", he clarified, "this proportion as to numbers in every trade finds itself and is never better kept than when nobody meddles or interferes with it" (I: 299-300). Mandeville's argument is that parents can be trusted to prepare their children for a trade or profession. In doing so, they confine themselves to their circumstances such that "he that can give but ten pounds with his son

${ }^{15}$ Imitation and emulation are important in Mandeville's sociology; he was aware that regularities which arise as a result of particular trends could have considerable social impact. 
must not look out for a trade where they ask one hundred for an apprentice". Even so, unlike the charity schools, they look out for the apprenticeship that is likely to be most advantageous (Mandeville 1924, I: 300). Mandeville did not deny that there were circumstances where the promotion of education was necessary for the development of the economy (such as in the Russia of Peter the Great). This, in his view, was not the case in England. Sound politics were to the social body what the art of medicine was to the natural; ergo, the appropriate intervention depended on the disease (I: 322). It was the business of the public to supply the defects of society, and take that in hand first that which is most neglected by private persons (I: 321).

While Mandeville was aware of the need to develop structures that incentivised people to act 'voluntarily' in ways which were useful even when it was unpleasant for them personally, he was sharply critical of those, such as Addison, Steele and Shaftsbury, who presented a vision of social harmony. In a satirical passage worthy of Swift, Mandeville pretended to have been converted to Shaftsbury's system: he alludes to an example of an industrious poor woman who scrimped and scraped in order to save the money needed to apprentice her six year old son to a chimney sweeper. Parodying Shaftsbury, Mandeville portrayed the story as follows:

she gives up her all, both offspring and estate, to assist in preventing the several mischiefs that are often occasioned by great quantities of soot disregarded; and, free from selfishness, sacrifices her only son to the most wretched employment for the public welfare" (II: 43-4).

The reader is left under no illusion that it is need that drives the woman's sacrifice, not her desire to promote the public good. ${ }^{16}$ As stated in the Introduction to his Inquiry into the origin of moral virtue, Mandeville's aim was to describe men as they really are, not teach them what they should be (I: 39). Similarly, with regard to society, Mandeville's interest was not the justification of the existing state of affairs or its presentation as harmonious, but in describing society as it was, warts and all.

\footnotetext{
${ }^{16}$ Conversely, in A Letter to Dion, Mandeville referred to hypocrites seeking to "persuade the world, [...] that they fed on trouts and turbots, quails and ortolans, and the most expensive dishes, not to please their dainty palates or their vanity but to maintain the fishmonger and the poulterer and the many wretches, who, for a miserable livelihood, are daily slaving to furnish them" (Mandeville 1953).
} 
Mandeville's treatment of the labour market won him the admiration of Marx who, in volume I of Capital, praised Mandeville as honest and clear-headed, and included lengthy quotations from volume I of the Fable which depicted the conditions necessary to make the poor laborious. Marx appreciated Mandeville's depiction of a class-based society and his views on what was necessary for its reproduction. However, Marx was aware that Mandeville lacked both a theory of capital and of its accumulation. As he put it, Mandeville had "not yet seen" that in the process of capital accumulation, wage labourers turn their labour power into an engine for the self-expansion of capital, and by doing so, reinforce their dependence upon their own product (Marx 1977, 576577).

\section{CONCLUSION}

Two forms of argument commonly associated with the laissez-faire principle can be found in Mandeville's thought. The first of these relates to the issue of government intervention. As has often been noted, Mandeville claimed that the allocation of the workforce between the different trades was best achieved when nobody meddled with it. The issue then arises: how is Mandeville's call for non-interference (by wellmeaning meddlers) to be reconciled with his equally clear assertion that private vices were turned into public benefits by the dexterous management of the skilful politician? Rosenberg's answer is that the dexterous management by the clever politician should be interpreted to mean the creation of a legal and institutional framework where arbitrary intervention by government would be minimised. Such a framework was not to be seen as the product of human ingenuity but evolved gradually over time through a process of trial and error (Rosenberg 1963). While Rosenberg's solution is widely accepted, it did not put an end to the debate about intervention but shifted it from being about direct interference in the economy to being about the role government in the creation of institutions. Whereas Rosenberg and Viner viewed institutions as being at least in part the product of wise government intervention, Hayek argued that institutions are the products of human activity but not human design and that this mandates a policy of nonintervention, or at best, cautious reform in the process of emergence.

Mandeville's concern about the limitations of human knowledge and rationality are visible throughout his work, particularly in part II of the Fable. But unlike Hayek, he never regarded the limitations of human 
knowledge as an excuse for inertia. For Mandeville, all knowledge was derived from experience and his heroes were those who put their hands to the plough and experimented. Mandeville certainly understood the complex nature of social institutions and the fact that this complexity meant that actions taken to eliminate some perceived evil did not always produce the desired effect. Part of the purpose of the Fable was to expand people's worldviews and thereby enable them to take account of unintended consequences (Mandeville 1924, I: 91). By looking at the concatenated chain of events, men could learn to reject some actions (e.g., the charity schools) and promote others (e.g., sustainable buildings and works; legal brothels). Mandeville took the view that competition generally produced positive results but he was aware that this was not always the case. The search for differential advantage could lead to the discovery of better ways of doing things but he was aware that, particularly in medicine, the search for advantage could hinder progress by providing incentives for the wrong kinds of activity. ${ }^{17}$

The second argument in support of the laissez-faire principle revolves around the notion of freedom. There are two versions of this argument. In one version, freedom has instrumental value in that it enables people to choose the best available outcome. In another version traditionally associated with natural law, market outcomes are considered just because they are entered into voluntarily. Mandeville believed that, when offered a choice, people make what seems to them to be the best choice available. However, he delighted in showing that sometimes the 'best' choice only looks palatable because it is comparably better than the worse alternatives. ${ }^{18}$ Thus, while a contractual relationship had to be based on the principle of mutual benefit, transactions in the labour market had to be underpinned by the compulsion of need. While such transactions could be regarded as fair in a system where honour had replaced virtue, they were a long way

\footnotetext{
${ }^{17}$ Mandeville believed that all knowledge resulted from experience. In medicine as in painting, theoretical knowledge alone did not prepare one for the practice of the art. However, physicians had found out that the means to achieve riches and reputation was by becoming expert in one of the many "shallow auxiliary arts" that formed part of the theory of physic. Mandeville stated that, "Where shall you find a physician nowa-days, that makes that stay with his patients [...] this would not only be too laborious, but a tedious was of getting money; self-interest now gives better lessons to young physicians" (Mandeville 1730, 39). The lessons were that if they had not achieved fame in one of the auxiliary arts, they should set about obtaining a reputation in other ways, such as becoming an author, a translator, marrying well, becoming a party man or holding court in the coffee houses.

${ }^{18}$ See Remark 'R' in volume I of the Fable (Mandeville 1924, I: 208-209).
} 
from being just in the sense required by the scholastic doctors in an earlier era.

In A letter to Dion, Mandeville acknowledged the bad reputation acquired by the Fable of the bees. His explanation for the book's ill repute was that his exposure of vice and luxury of the time had earned him a great number of enemies: "Few men can bear with patience, to see those things detected, which it is their interest, and they take pains to conceal" (Mandeville 1953). But if Mandeville was willing to expose the faults of the emerging market system, he was also a powerful advocate of its strengths:

To this emulation and continual striving to outdo one another it is owing, that [...] there is still a plus ultra left for the ingenious; it is this, or at least the consequence of it, that sets the poor to work, adds spurs to industry, and encourages the skilful artificer to search after further improvements (I: 130).

The emulation and striving which drove progress had to be accommodated but if unregulated it could become an obstacle to development. Rules of the game were necessary and evolved over time. Society was "a body politic, in which man, either subdued by superior force, or by persuasion drawn from his savage state, is become a disciplined creature, that can find his own ends in labouring for others" (I: 347). There is no presumed harmony of interests: "the temporal happiness of some is inseparable from the misery of others. They are silly people who imagine that the good of the whole is consistent with the good of every individual" (Mandeville 1953: 49). Mandeville sought to understand how such a system could still appear to operate on the basis of the voluntary actions of the individual. In so doing, he recognised both the importance of evolved institutions and the limitations of apparent voluntary action.

\section{REFERENCES}

Arthur, W. Brian. 1989. Competing technologies, increasing returns, and lock-in by historical events. Economic Journal, 99 (394): 116-131.

Bianchi, Maria. 1993. How to learn sociality: true and false solutions to Mandeville's problem. History of Political Economy, 25 (2): 209-240.

Bitterman, Henry J. 1940. Adam Smith's empiricism and the law of nature II. Journal of Political Economy, 48 (5): 703-734.

Brennan, Geoffrey 2013. Liberty matters. James Buchanan: an assessment. Indianapolis: Liberty Fund. 
Buchanan, James M. 1975. The limits of liberty: between anarchy and leviathan. Chicago: University of Chicago Press.

Caldwell, Bruce. 2000. The emergence of Hayek's ideas on cultural evolution. Review of Austrian Economics, 13(1): 5-22.

Chalk, Alfred F. 1966. Mandeville's Fable of the bees: a reappraisal. Southern Economic Journal, 33 (1): 1-16.

David, Paul A. 1985. Clio and the economics of QWERTY. The American Economic Review, 75 (2): 332-337.

Fiori, Stefano. 2006. The emergence of institutions in Hayek's theory: two views or one. Constitutional Political Economy, 17 (1): 49-61.

Friedman, Milton. 1991. Economic freedom, human freedom, political freedom. Lecture delivered 1 November at The Smith Center-A Conservative Think Tank at Cal State Hayward. www.calculemus.org/lect/07pol-gosp/frlect.html (accessed January 4, 2016).

Gray, John. 1989. Liberalisms. London: Routledge.

Hayek, Friedrich A. 1991. Dr. Bernard Mandeville. In vol. III, The collected works of F.A. Hayek, eds. William Warren Bartley III and Stephen Kresge. London: Routledge, 7496.

Hobbes, Thomas. 1999 [1640]. The elements of law natural and politic, ed. John Charles Addison Gaskin. Oxford: Oxford University Press.

Hobbes, Thomas. 2001 [1651]. Of man, being the first part of Leviathan. New York: P.F. Collier \& Son. www.bartleby.com/br/03405.html (accessed January 2016).

Keynes, John Maynard. 1926. The end of laissez-faire. London: Hogarth Press.

Krugman, Paul. 1991. Increasing returns and economic geography. Journal of Political Economy, 99 (3): 483-99.

Landreth, Harry. 1975. The economic thought of Bernard Mandeville. History of Political Economy, 7 (2): 193-208.

Langholm, Odd. 1982. Economic freedom in scholastic thought. History of Political Economy, 14 (2): 260-283.

Lupton, Sylvie. 2015. Quality uncertainty in early economic thought. History of Political Economy, 47 (3): 511-534.

Mandeville, Bernard. 1724. A modest defence of public stews: or, an essay upon whoring. London: A. Moore.

Mandeville, Bernard. 1730. A treatise of the hypochondriack and hysterick diseases. In three dialogues. London: J. Tonson.

Mandeville, Bernard., 1924. The fable of the bees, ed. F.B. Kaye, 2 vols. Oxford: Clarendon Press.

Mandeville, Bernard. 1953 [1732]. A letter to Dion. Los Angeles: Augustan Reprint Society.

Marx, Karl. 1977. Capital: A critique of political economy. London: Lawrence and Wishart.

Marx, Karl. 1988. Karl Marx and Fredrick Engels, collected works. Vol. 30, 1861-63. London: Lawrence \& Wishart.

Moss, Laurence S. 1987. The subjectivist mercantilism of Bernard Mandeville. International Journal of Social Economics, 14 (3/4/5): 167-184. 
Porter, Michael E. and Claas. van der Linde. 1995. Toward a new conception of the environment -competitiveness relationship. Journal of Economic Perspectives, 9 (4): 97-118.

Prendergast, Renee. 2010. Accumulation of knowledge and accumulation of capital in early theories of growth and development. Cambridge Journal of Economics, 34 (3): 413-431.

Prendergast, Renee. 2014. Knowledge, innovation and emulation in the evolutionary thought of Bernard Mandeville. Cambridge Journal of Economics, 38 (1): 87-107.

Primer, Irwin. 2006. Bernard Mandeville's 'A modest defence of public stews'. London: Palgrave.

Rashid, Salim. 1985. Mandeville's Fable: laissez-faire or libertinism. Eighteenth Century Studies, 18 (3): 313-330.

Rosenberg, Nathan. 1963. Mandeville and laissez-faire. Journal of the History of Ideas, 24 (2): 183-196.

Rutherford, Malcolm. 2001. Institutional economics: then and now. Journal of Economic Perspectives, 15 (3): 173-194.

Schumpeter, Joseph. 1908. Das Wesen und der hauptinhalt der theoretischen Nationalökonomie. Leipzig: Duncker \& Humbolt.

Skarbek, Emily. 2013. F.A. Hayek and the early foundations of spontaneous order. In F.A. Hayek and the modern economy, eds. Sandra J. Peart and David M. Levy. London: Palgrave Macmillan, 101-117.

Sober, Elliott and David Sloan. Wilson. 1988. Unto others: the evolution and psychology of unselfish behaviour. Cambridge (MA): Harvard University Press.

Spengler, Joseph J. 1959. Adam Smith's theory of economic growth: part I. Southern Economic Journal, 25 (4): 397-415.

Steele, David R. 1987. Hayek's theory of cultural group selection. Journal of Libertarian Studies 8 (2): 171-195.

Viner, Jacob. 1937. Studies in the theory of international trade. New York: Harper and Brothers.

Viner, Jacob. (ed.). 1953. Introduction. Reprint of B. Mandeville, A letter to Dion, 1732. Los Angelos: Augustan Reprint Society, 1-15.

Viner, Jacob. 1960. The intellectual history of laissez faire. Journal of Law and Economics, 3: 45-69.

Viner, Jacob. 1961. Hayek on freedom and coercion. Southern Economic Journal, 27 (3): 230-236.

Voight, Stefan. 1992. On the internal consistency of Hayek's evolutionary oriented constitutional economics-some general remarks. Journal des Économistes et des Études Humaines, 3 (4): 461-476.

Whitman, Douglas Glenn. 1998. Hayek contra Pangloss on evolutionary systems. Constitutional Political Economy, 9 (1): 45-66.

Renee Prendergast is reader in economics at Queens' Management School, Belfast.

Contact e-mail: <r.prendergast@qub.ac.uk> 